\title{
AL-QUR'AN, JALAN ILMU PENGETAHUAN DAN PERUBAHAN SOSIAL
}

\author{
Piet Hizbullah Khaidir \\ Sekolah Tinggi Ilmu Al-Qur'an dan Sains Al-Ishlah (STIQSI) \\ Sendangagung Paciran Lamongan \\ Email: piet@alishlah.ac.id
}

\begin{abstract}
Abstrak
Menurut teori perubahan sosial (al-taghyir al-ijtima'iy) dan peradaban (alhadlarah wa al-tsaqafah), misalnya seperti dilansir oleh Ibn Khaldun dalam Kitab Muqaddimahnya, dinyatakan bahwa tonggak peradaban yang darinya lahir perubahan sosial itu ditopang oleh unsur luhur kemanusiaan, yaitu: ilmu pengetahuan (budaya baca-tulis), karya peradaban dan upaya bertahan hidup. Semakin tinggi tradisi baca-tulis dimiliki oleh suatu masyarakat, semakin memungkinkannya mereka melakukan perubahan sesuai kemajuan zaman yang dibutuhkan. QS. Al-'Alaq: 1-5 memberi kita pengertian bahwa pilar peradaban Islam dibentuk oleh tiga gerakan: baca-tulis, spiritual dan amal shaleh. Tiga gerakan tersebut menunjukkan bahwa suatu komunitas perlu memancangkan tiga tradisi gerakan tersebut dalam pikiran dan aktifitasnya untuk menjadi semacam strategi perubahan sosial bila hendak mencapai suatu peradaban seperti dicanangkan al-Qur'an. Tiga tradisi gerakan yang disebutkan dalam QS. Al'Alaq: 1-5 di atas menjadi lebih menarik dan penting bila dikaitkan dengan pembacaan ayat-ayat lainnya, misalnya QS. Al-Ra'du: 11 dan Al-Anfal: 53; AlRahman: 33; Al-Mujadilah: 11; serta Al-Fatihah dan Al-Muzammil. Tulisan ini, dengan metode pembacaan terhadap ayat-ayat tersebut, dengan menggunakan pendekatan munasabat ayat dan teori perubahan sosial, hendak mengkaji dan mendalami apa dan bagaimana perubahan sosial menurut al-Qur'an; serta apa dan bagaimana strategi perubahan sosial dan tujuan akhir (ghayah) dari konsep perubahan sosial dalam al-Qur'an. Kemudian, aktor perubahan sosial seperti apa dan bagaimana yang dicanangkan Al-Qur'an dalam melakukan perubahan sosial.
\end{abstract}

Kata Kunci: Perubahan Sosial, Strategi Perubahan Sosial, Aktor Perubahan Sosial.

\section{Pendahuluan}

Supaya dapat dibaca lebih kontekstual, tulisan ini akan diawali dengan sebuah cerita tentang perubahan sosial berbasiskan pada perubahan diri yang dilakukan oleh seseorang. Kisah tentang anak muda belia yang mencapai citacitanya dengan gemilang, karena upayanya melakukan perubahan. Dimulai dari keyakinannya melakukan perubahan mindset untuk menjadi pribadi yang 


\section{Piet Hizbullah Khaidir}

konsisten, memiliki integritas dan disiplin tinggi dalam belajar, dan pada saat yang sama tetap dalam kesederhanaan dan kerendah-hatian.

Pada hari Ahad, 09 September 2018, ${ }^{1}$ seorang petenis muda berkewarganegaraan Jepang bernama Osaka Naomi memenangkan pertandingan tenis lapangan melawan Serena William di US Tennis Open Tournament 2018. Dia berhasil mengalahkan idolanya, petenis perempuan tangguh yang telah memenangkan sebanyak 23 kali tournament yang sama. Pertandingan yang cukup dramatis itu diakhiri hujan tangis haru. Ada tiga penyebabnya. Pertama, kerendahhatian Osaka Naomi yang mengatakan bahwa sebenarnya yang berhak memperoleh piala ini adalah Serena Williams, sang idola. "Tetapi, saya memperoleh kehormatan untuk mendapatkannya. Terima kasih, Serena", tegasnya. $^{2}$

Kedua, Osaka Naomi hijrah ke Amerika sejak belum masuk Sekolah Dasar dengan tujuan untuk belajar tenis lapangan. Mimpi yang dibarengi tekad yang mantap untuk belajar, disertai integritas, disiplin tinggi dan konsistensi penuh untuk meraih kesuksesan adalah mindset positif yang terbentuk dalam karakter dirinya. Yang patut dicatat di sini adalah bahwa perubahan mindset, belajar giat, disiplin dan integritas diri adalah prasyarat perubahan sosial untuk mencapai kesuksesan.

Ketiga, meskipun sejak sebelum Sekolah Dasar telah hijrah ke Amerika, karakter santun dan rendah hati ala orang Jepang sama sekali tidak berubah. Justru semakin teguh dipegang sebagai karakter diri. Ini tentu saja membuat Jepang bangga terhadapnya.

Yang dapat kita pelajari dari Naomi adalah: ia pekerja keras, rendah hati, integritas kebangsaan dan karakter dirinya kuat, selalu belajar mengembangkan diri, dan itu semua adalah mindsetnya untuk menggapai cita-cita dengan tekun dan semangat. Jadi, kata kuncinya adalah perubahan mindset itu penting untuk meraih mimpi-mimpi besar.

\footnotetext{
https://www.youtube.com/watch?v=jCm3BemDlj8 (winning speech); https://www.youtube.com/watch?v=aFWwO7RR2QM (match Serena Vs Naomi), last accessed 30 September 2019, at 15:54

${ }^{2}$ Ibid.
} 


\section{Pentingnya Perubahan Mindset}

M.K. Bacchus mengisahkan dalam artikelnya berjudul Education, Cultural Change and Cultural Pluralism ${ }^{3}$ bahwa perubahan mindset yang dialami seseorang dalam komunitasnya, atau dialami komunitas orang ketika bersinggungan dengan komunitas lainnya, disebabkan oleh situasi riil yang dihadapinya. Misalnya, masyarakat Guyana yang merupakan budak, setelah pembebasan sebagai budak, mereka dicerahkan dengan ceramah dan penyuluhan mengenai pentingnya pendidikan. Mereka ingin berubah hidupnya. Mereka kemudian mengisi hidupnya dengan belajar, memperoleh pengetahuan, bersekolah. Tetapi, situasi perolehan hasil pendidikan oleh orang-orang Guyana ini tidak diperhatikan oleh pihak berwenang. Keterlibatan mereka dalam bersekolah tidak dihargai. Misalnya, penerimaan kerja di sebuah tempat bukan karena pendidikannya, melainkan karena kedekatan ideologis, karena kasta sosial.

Mengalami situasi seperti di atas, masyarakat Guyana awalnya jengkel dan tidak mau bersekolah lagi. Mereka hampir saja antipati terhadap pendidikan. Namun demikian, untungnya mereka menyadari bahwa melalui pendidikan mereka bisa berubah dan memiliki pengetahuan serta wawasan yang luas. Oleh karena itu, pada akhirnya masyarakat Guyana yang semula menganggap pendidikan seperti momok menakutkan, bahkan seolah tidak bermanfaat bagi masa depan mereka, sekarang mereka mulai memperhatikannya dengan seksama. ${ }^{4}$ Inilah salah satu contoh bentuk perubahan mindset.

Mindset itu sedikit banyak berpengaruh terhadap keberhasilan seseorang. Perubahan mindset, yakni dengan memilih mindset yang baik dan relevan akan melahirkan perubahan, tidak hanya perubahan diri, lebih jauh perubahan sosial. Bahkan bila dibarengi dengan ketepatan momentum, integritas dan disiplin belajar yang kuat, perubahan mindset akan diikuti keberhasilan yang nyata. Jadi perubahan mindset adalah keharusan jika seseorang menginginkan adanya kemajuan positif dalam dirinya dan komunitasnya.

QS. Al-Ra'du: 11 menegaskan tentang pentingnya perubahan agar suatu kaum dapat mengubah keadaannya. Berikut ayat QS. Al-Ra'du: 11:

\footnotetext{
${ }^{3}$ M.K. Bacchus, Education, Cultural Change and Cultural Pluralism, JSTOR Sociology of Education, Vol. 42/4, 1969, hal. 369-372

${ }^{4}$ Ibid.
} 


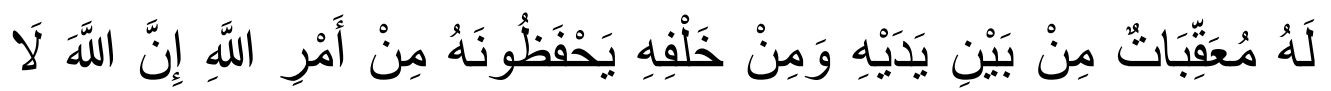

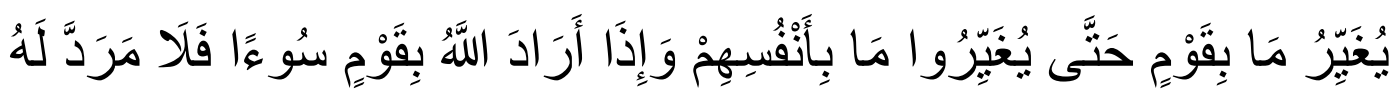

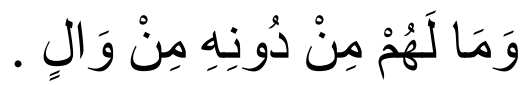

Terjemahan lengkapnya adalah: "Bagi manusia ada malaikat-malaikat yang selalu mengikutinya bergiliran, di muka dan di belakangnya, mereka menjaganya atas perintah Allah. Sesungguhnya Allah tidak merubah keadaan sesuatu kaum sehingga mereka merubah keadaan yang ada pada diri mereka sendiri. Dan apabila Allah menghendaki keburukan terhadap sesuatu kaum, maka tak ada yang dapat menolaknya; dan sekali-kali tak ada pelindung bagi mereka selain Dia." ${ }^{, 5}$

"Allah tidak akan mengubah mindset (ما) suatu kaum, bila kaum itu tidak mengubahnya." Pilihan mindset dari mindset-mindset yang tersedia dalam konteks surat di atas adalah mengikuti ajaran nabi, jalan petunjuk serta syariat Allah Swt. Ketika seseorang meyakini suatu mindset, terpatri dalam dirinya, pikirannya, sanubarinya, dan kemudian menjadi karakter pola pikirnya, dia akan mencapai hasil yang maksimal. Oleh karena itu, seperti disebutkan oleh QS. AlRa'du: 11 di atas, dan kemudian dipertegas oleh QS. Al-Anfal: 53, perubahan mindset terkait dengan keyakinan terhadap nikmat Allah berupa ajaran Nabi Muhammad Saw, petunjuknya dan syariat Allah, lalu dengan pasrah total seseorang bersedia untuk mengikutinya dengan baik. Keraguan mengikuti ajaran Nabi, jalan petunjuknya, serta syariat Allah yang dibawanya, karena tidak mau mengubah mindset berpikir dengan tetap mengikuti tradisi Jahiliyah, akan berakibat kurang bagus. Berakibat terciptanya neraka di hati dan pikirannya. Keraguan adalah mindset yang buruk.

Berikut teks lengkap QS. Al-Anfal: 53 dan terjemahannya:

${ }^{5}$ https://ayatalquran.net/2014/12/surah-ar-radu-terjemah-bahasa-indonesia/, last accessed 01 October 2019, at 12:17.

${ }^{6}$ Al-Qur'an Al-Karim dan Terjemahannya, Khadim al-Haramayn, 1418 H., hal. 370. Dalam catatan nomor 768, dalam menjelaskan makna keadaan, Al-Qur'an dan Terjemahannya cetakan Saudi Arabia ini menyatakan bahwa "Tuhan tidak akan mengubah keadaan kaum (mereka), selama mereka tidak mengubah sebab-sebab kemunduran mereka.” 


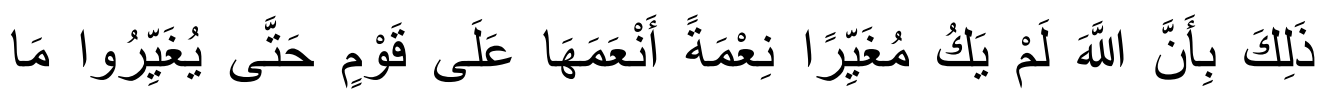

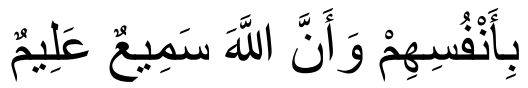

"(Siksaan) yang demikian itu adalah karena sesungguhnya Allah sekali-kali tidak akan meubah sesuatu nikmat yang telah dianugerahkan-Nya kepada suatu kaum, hingga kaum itu meubah apa-apa yang ada pada diri mereka sendiri, dan sesungguhnya Allah Maha Mendengar lagi Maha Mengetahui.",

Terhadap QS. Al-Ra'du: 11, Sayyid Quthb dalam Tafsir Fii Zilalil Qur'an, mengatakan bahwa yang harus dilakukan seseorang atau suatu kaum dalam melakukan perubahan adalah meyakinkan diri setiap anggota suatu kaum tersebut agar selalu mengikuti sunnatullah. Sunnatullah itu rumusnya adalah kebajikan semesta. Katanya: "Berlakulah kehendak dan sunnah Allah bahwa sunnah-Nya pada manusia itu berlaku sesuai dengan sikap dan perbuatan manusia itu sendiri dan berlakunya sunnah-Nya pada mereka itu didasarkan pada bagaimana perilaku mereka dalam menyikapi sunnah ini". 8 Sunnatullah dalam konteks makna sebagaimana disebut Sayyid Quthb di atas matched dengan mindset.

Sebagaimana tercatat dalam sejarah, orang yang memiliki perubahan mindset yang positif akan memperoleh kebajikan dengan kesuksesan yang gemilang. Dalam praktiknya, perubahan mindset membutuhkan kesiapan mental yang kuat, tangguh dan kreatif agar seseorang yang telah mencapai derajat ini, benar-benar bisa konsisten serta setia terhadap kebajikan yang ditekuni dalam semua aktifitasnya.

Perubahan mindset dengan demikian dalam kaitannya dengan aktornya merupakan masa pembentukan mental dan perkaderan di dalam ruang eksistensial penyiapan diri untuk memperoleh ilmu pengetahuan yang aplikatif. Ilmu pengetahuan yang aplikatif ini terkait dengan perubahan mindset yang selalu berkoinsiden dengan jalan ilmu. Bagaimana mungkin seseorang dapat berubah mindsetnya tanpa jalan ilmu pengetahuan, seperti masyarakat Guyana sebagaimana telah disebutkan di atas.

\footnotetext{
7 https://ayatalquran.net/2014/12/surah-al-anfaal-terjemah-bahasa-indonesia/, last accessed $01 / 10 /{ }^{\prime} 19$, at $12: 50$

${ }^{8}$ Sayyid Quthb, Tafsir Fi Zilalil Qur'an, Jilid VII, Gema Insani, Depok, 2004, hal. 38.
} 


\section{Piet Hizbullah Khaidir}

\section{Perubahan Mindset dan Jalan Ilmu}

Ada sinergi antara perubahan mindset dan jalan ilmu pengetahuan. Oleh karena itu, keyakinan penting sebagai premis utama strategi perubahan sosial dalam Al-Quran adalah perubahan mindset. Individu atau kumpulan individu yang ingin melakukan perubahan sosial, perlu perubahan terhadap pola dan cara berpikirnya. Perlu dipertegas lagi, bahwa premis Al-Quran Surat Al-Ra'du: 11 dan Surat Al-Anfal: 53 menyatakan bahwa seseorang secara sendiri ataupun berkelompok tidak akan diubah mindset-nya oleh Allah, sampai mereka mengubah sendiri dengan cara mengikuti mindset (kebenaran cahaya) yang dipilihkan Allah untuk mereka.

Menariknya, QS. Al-Ra'du: 11 seperti dikutip di atas, dinyatakan dengan huruf penegasan "inna", kemudian diikuti huruf "la" (nafyi) bersama "kata kerja mudlari'“. Sedangkan Al-Anfal: 53 menggunakan ushlub dengan huruf penegasan "inna" ditambah huruf jazm "lam" bersama kata kerja kana dalam bentuk mudlari' diikuti isim fa'il. Menurut kaidah gramatikal Bahasa Arab, huruf inna menunjukkan penegasan atas sesuatu yang secara rasional dan empiris telah jelas hukumnya. Adapun, menurut al-Baghawi, fi'il mudlari' menandaskan tentang kejadian yang berlangsung terus-menerus; dan fi'il kana dalam bentuk mudlari' ditambah isim fa'il menegaskan tentang keberlangsungan yang terus-menerus bahwa isim fa'il yang disebutkan melakukan sendiri. ${ }^{9}$

Dengan demikian, Al-Ra'du dan Al-Anfal di atas menegaskan suatu premis: "Kalau seorang individu baik sendiri atau berkelompok tidak melakukan perubahan mindset, perubahan sosial tidak akan pernah terjadi secara terusmenerus". Jadi kata kunci perubahan sosial ada pada kemauan individu secara bersama-sama untuk melakukan perubahan mindset. Perubahan mindset itu adalah nikmat Allah yang harus disyukuri dan ditunjukkan dengan mewujudkannya secara sungguh-sungguh.

Perubahan mindset bisa dilakukan dengan jalan membaca, menulis dan gerakan pencerahan lainnya. Pendeknya, adalah jalan ilmu. Sebenarnya perubahan mindset dan jalan ilmu adalah dua mata koin yang tidak bisa dipisahkan. Orang

9 Al-Syaikh Ibn Al-Farra' Al-Baghawi, Tafsir Al-Baghawi, Dar Ihya Al-Turats Al-Arabiy, Beirut, 1420 H, dalam Maktabah Syamilah Ar-Rawdah (www.shamela.ws) cetakan ke-7. 
yang sudah melakukan perubahan mindset, dia telah bersiap diri di jalan ilmu. Sedangkan orang yang bergerak di jalan ilmu, telah dan akan terus memperbarui mindsetnya. Inilah yang diurai oleh QS. Al-‘Alaq: 1-5; Al-QS. Mujadilah: 11 dan Al-Rahman: 33. Secara spesifik, proses membaca dan menulis diikuti gerakan pencerahan sebagaimana dikandung oleh Al-'Alaq adalah jalan ilmu yang dapat mengantarkan seseorang kepada perubahan mindset. Menariknya, dalam QS. Al'Alaq: 4, dinyatakan bahwa membaca harus diikuti dengan menulis, dengan alat qalam (pena) yang disebutkan dalam bentuk makrifah (al-qalam). Jadi, implikasi penyebutan dengan lafazh makrifah itu menegaskan sebuah makna "menulis bukan dengan sembarang alat tulis. Melainkan alat tulis yang ketika dipergunakan untuk menulis benar-benar menginspirasi dan menggerakkan pembaca berikutnya untuk melakukan kebajikan semesta. Sebagaimana ayat lanjutannya menjelaskan, seolah dengan pena itu, orang yang sudah melakukan perubahan mindset dan fokus di jalan ilmu, akan menginspirasi dan menggerakkan pencerahan terhadap pembacanya, seolah seperti "Allah mengajarkan insan apa yang tidak diketahuinya". 10

Orang tersebut di atas adalah orang yang dikaruniai nikmat memiliki sulthan (ilmu pengetahuan) dan karena itu akan dapat menembus langit dan bumi, sebagaimana penjelasan Al-Rahman: 33. Orang ini karena keyakinan dan pengetahuannya, seperti ditegaskan Al-Mujadilah: 11, diangkat derajatnya oleh Allah, dan sikapnya selalu dilandasi lapang dada dan wawasan yang luas (tafassuh fil majalis dan nusyzun). Dengan kata lain, orang sebagaimana dijelaskan oleh Al'Alaq, Al-Rahman dan Al-Mujadilah inilah tipologi individu yang dapat melakukan perubahan sosial.

\section{Konsep Sulthan}

Konsep sulthan disebutkan dalam QS. Al-Rahman: 33 dengan teks lengkap dan terjemahannya sebagai berikut:

${ }^{10}$ Al-Qur'an dan Terjemahnya, Khadim al-Haramain, 1418 H, hal. 1079. Disebutkan dalam catatan kaki nomor 1590, menjelaskan 'mengajarkan manusia dengan perantaraan qalam, maksudnya adalah "Allah mengajar manusia dengan perantaraan tulis baca". 


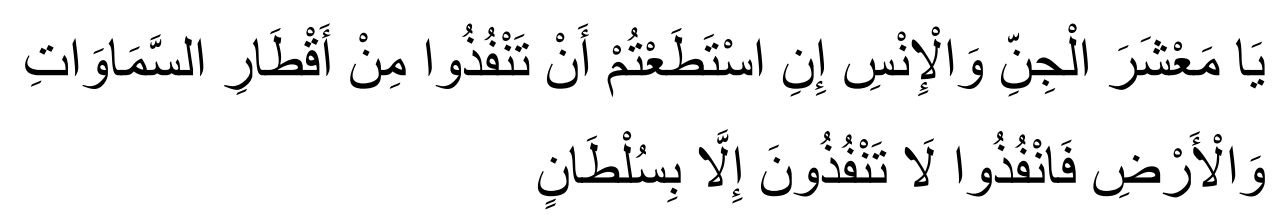

"Hai jama'ah jin dan manusia, jika kamu sanggup menembus (melintasi) penjuru langit dan bumi, maka lintasilah, kamu tidak dapat menembusnya kecuali dengan kekuatan." 11

Agar mampu melintasi penjuru langit dan bumi, golongan jin dan manusia diperintahkan oleh Allah, sebagaimana disebut dalam QS. 55: 33 di atas, untuk memohon pertolongan kekuatan dari Allah. Karena mereka tidak akan sanggup menembus penjuru langit dan bumi tanpa maunah kekuatan dari Allah Swt. ${ }^{12}$

Tafsir Al-Qurthubi ${ }^{13}$ menafsirkan QS. 55: 33 dengan sangat indah. Yaitu, dengan mengutip penjelasan Ibnu Abbas, Al-Qurthubi mencatat tafsir QS. 55: 33 sebagai berikut: "Jika kalian ingin mengetahui penjuru langit dan bumi, maka berusahalah tahu dengan mengurai ilmu pengetahuan (' $\mathrm{ilm}$ ) tentangnya. Dan kalian tidak akan pernah mencapai ilmu pengetahuan tentang penjuru langit dan bumi itu kecuali dengan sulthan. Sulthan itu adalah penjelasan langsung dari Allah Swt". ${ }^{14}$ Juga mengutip pendapat Qatadah, bahwa sulthan adalah kekuasaan (sulthan wa mulk) dan kemampuan (qudrah) Allah. ${ }^{15}$ Al-Baghawi menegaskan bahwa makna sulthan adalah kekuasaan (mulk), kemampuan (qudrah) dan argumentasi ilmu pengetahuan (hujjah). ${ }^{16}$

Dari uraian penafsiran di atas, menurut kami, secara singkat dan sederhana, sulthan sebagai konsep ilmu pengetahuan, tradisi, dan proses penguasaan bumi dan langit bisa diklasifikasi sebagai berikut: (i) ilmu pengetahuan (konseptual dan teknis); (ii) manajemen leadership; dan (iii) kemampuan berkomunikasi interpersonal yang hebat. Sesuai petunjuk Al-Qur'an dengan penafsiran di atas, ketika seseorang akan melakukan suatu upaya menguasai atau menembus melintasi langit dan bumi, maka dia harus memiliki dan menguasai sulthan. Yaitu,

\footnotetext{
$11 \quad$ https://ayatalquran.net/2014/12/surah-ar-rahman$\% \mathrm{~d} 8 \% \mathrm{a} 7 \% \mathrm{~d} 9 \% 84 \% \mathrm{~d} 8 \% \mathrm{~b} 1 \% \mathrm{~d} 8 \%$ ad $\% \mathrm{~d} 9 \% 85 \% \mathrm{~d} 9 \% 86$-terjemah-bahasa-indonesia/, last accessed $01 / 10 / ' 19$, at $12: 38$

${ }^{12}$ Lihat Qur'an Kemenag, Aplikasi Mushaf Digital, Kemenag RI, cq. Lajnah Pentashhihan Mushaf Al-Qur'an, 2007, Jakarta

${ }^{13} \mathrm{Al}-$ Syaikh Al-Qurthubi, ibid.

${ }^{14}$ Ibid.

15 Ibid.

${ }^{16}$ Al-Syaikh Ibn Al-Farra’ Al-Baghawiy, Ibid.
} 
penguasaan ilmu pengetahuan yang dibutuhkan dalam rangka melakukan penguasaan langit dan bumi. Ilmu pengetahuan tersebut harus dikuasai mulai dari bentuk konseptualnya sampai teknis fungsionalnya.

Setelah itu, seseorang diharapkan dapat melakukan proses kepemimpinan visioner yang bisa diterapkan ketika orang tersebut telah memiliki kekuasaan. Karena itulah sulthan juga bisa dipahami sebagai ilmu pengetahuan tentang manajemen, terutama manajemen kepemimpinan (leadership management). Lebih dari itu, seseorang harus memiliki relasi interpersonal yang baik, tidak canggung dan tetap tulus serta luwes. Untuk meyakinkan orang atau khalayak luas, dengan harapan ilmu pengetahuan yang bersifat konseptual dan teknis telah berhasil dieksplorasi dengan baik, serta didukung oleh menejemen leadership yang kuat, dibutuhkan komunikasi interpersonal yang visioner sekaligus luwes, agar benarbenar dapat tersampaikan pesan visionernya kepada khalayak luas. Di samping itu, agar pesan visioner kepemimpinan jalan ilmu pengetahuan dapat ditangkap secara massif dalam benak pikiran khalayak luas, lalu dapat mewujud membumi. Sulthan sebagai hujjah adalah ruang dan cara meyakinkan dan melobi orang lain agar sesuai dengan prinsip nilai kebajikan.

Tentu saja, tiga makna simpulan dari sulthan di atas adalah bentuk penggemblengan diri eksistensial terhadap siapapun yang ingin melakukan perubahan sosial. Proses tarbiyah yang konsisten dan berintegritas dengan menggunakan konsep perubahan mindset dan pembumian konsep sulthan itu, dapat dijadikan semacam panduan visioner dalam melahirkan aktor perubahan sosial sejati. Lalu, bagaimana seorang aktor perubahan sosial berproses mencapai konsep makna perubahan mindset dan sulthan itu dalam proses pendidikan yang dijalaninya? Mengacu kepada visi QS. Al-'Alaq: 1-5, prosesnya dapat dilakukan dengan menggunakan metode iqra' dan istiqra'. Dengan kata lain, untuk menggapai pribadi eksistensial dengan predikat sulthan dan siap sedia melakukan perubahan mindset dengan basis kebajikan universal, seorang aktor perubahan sosial harus melakukan secara konsisten dan berintegritas konsep iqra' dan istiqra'. 


\section{Piet Hizbullah Khaidir}

\section{Sulthan sebagai Jalan Eksistensial Ilmu Pengetahuan}

Sebagaimana disebutkan di atas, dapat dikatakan bahwa sulthan adalah jalan eksistensial ilmu pengetahuan. Analogi jalan eksistensial ilmu pengetahuan itu dapat dimengerti dengan penjelasan mengenai visimisi Ilahi dalam sejarah pewahyuan. Sebagaimana dicatat dengan tebal, visi-misi pewahyuan awal Al-Qur'an adalah gerakan perubahan revolusioner terhadap tradisi buta huruf dan buta aksara, sekaligus gerakan perubahan revolusioner terhadap buta mata hati dan buta akhlak. Kemudian, dilanjutkan dengan visi-misi penghambaan pada kebenaran dan penghormatan pada harkat martabat manusia. Cara mencapai perolehan mental kreatif dan bermartabat seorang aktor perubahan sosial adalah melalui jalan ilmu dan integritas kedisiplinan, keterbukaan berpikir (open minded dan humble) dan kehebatan dalam mengendalikan diri. Itulah yang tergambar dalam QS. Al-'Alaq: 1-5. Dengan kata lain, jalan pribadi sulthan secara eksistensial adalah jalan pendakian terus-menerus untuk belajar dan berdisiplin belajar. Demikianlah jalan ilmu pengetahuan Al-Qur'an. Berikut teks lengkap dan terjemahannya: ${ }^{17}$

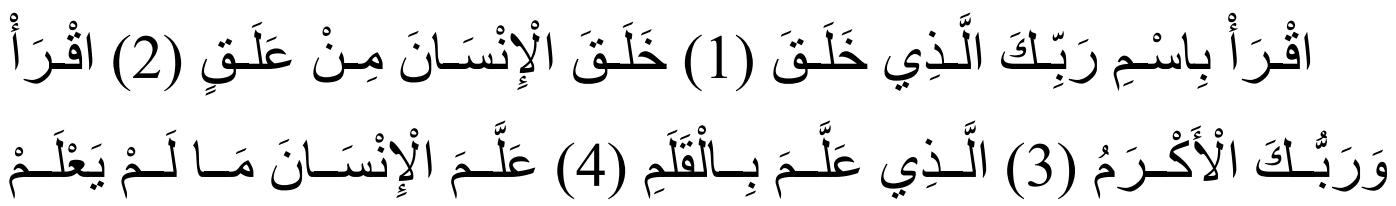

(1) Bacalah dengan (menyebut) nama Tuhanmu Yang menciptakan,

(2) Dia telah menciptakan manusia dari segumpal darah.

(3) Bacalah, dan Tuhanmulah Yang Maha Pemurah,

(4) Yang mengajar (manusia) dengan perantaran kalam,

(5) Dia mengajar kepada manusia apa yang tidak diketahuinya.

Al-Qur'an memberi informasi kepada kita bagaimana seorang mukmin secara das solen mencari ilmu, berperilaku dengan ilmu, serta menggunakan ilmu. Gambaran informatif tersebut di atas mengantarkan kita para pengkaji Al-Qur'an $\% \mathrm{~d} 8 \% \mathrm{a} 7 \% \mathrm{~d} 9 \% 84 \% \mathrm{~d} 8 \% \mathrm{~b} 9 \% \mathrm{~d} 9 \% 84 \% \mathrm{~d} 9 \% 82$-terjemah-bahasa-indonesia/, last accessed 01/10/'19, at $12: 41$
} 
kepada aspek ontologi, ${ }^{18}$ epistemologi ${ }^{19}$ serta aksiologi ${ }^{20}$ Al-Qur'an. Yakni, ilmu dalam Islam akan mengarahkan kepada pengakuan akan: (i) hakekat wujud akhir yang hakiki, bukan bendawi; (ii) ilmu pengetahuan yang bersumber dari cahaya mutlak wujud hakiki, dus ilmu yang bersumber demikian akan mencerahkan; serta (iii) ilmu pengetahuan yang bermuara kepada pertanggung-jawaban moral sebagai ilmu dan nilai.

Dalam skema inilah, konsep pendidikan dalam Islam dalam rangka mencapai peradaban melalui proses perubahan sosial itu bersifat komprehensif, yakni membahas apa ilmu itu, bagaimana cara mencari ilmu, sumber ilmu, muara mencari ilmu, juga tentang siapa pencari ilmu dan siapa orang yang berilmu itu, serta apa dan bagaimana keterkaitan ilmu dengan moral dan nilai. Dengan kata lain, bila secara sederhana dikaitkan dengan pembentukan mental kreatif dan bermartabat dari aktor perubahan sosial, proses tarbiyah itu harus memahamkan kepada mereka agar mengetahui dengan benar apa yang dipelajari, bagaimana cara mencari ilmu yang benar, bagaimana ilmu yang dipelajari menjadi pelita cahaya dirinya dan juga orang sekitarnya.

Dalam pengembangan dan perkembangan ilmu pengetahuan, Al-Qur'an dinilai memberikan inspirasi dan cahaya etis bagi pembacanya untuk mencintai ilmu dan mengembangkan ilmu pengetahuan sebagai lentera kehidupan manusia. Dalam sejarah ilmu pengetahuan, kaum muslimin dengan sinaran cahaya etis keilmuan Al-Qur'an telah mengembangkan berbagai penelitian yang melahirkan ilmu pengetahuan dan teknologi. Intinya, Al-Qur'an sebagai pedoman sinaran etis ilmiah telah membuktikan peranannya yang begitu dahsyat sebagaimana dibuktikan misalnya dalam sejarah peradaban dan ilmu pengetahuan Islam di Baghdad dan Cordoba. Al-Qur'an dengan Iqra' dan Istiqra'nya telah membuktikan diri secara eksistensial telah melahirkan generasi bermental kreatif dan bermartabat yang siap melakukan perubahan sosial, sehingga peradaban Islam dan nilai Islam tetap agung dalam lintasan sejarah.

\footnotetext{
${ }^{18}$ Ontologi adalah cabang filsafat yang meyelidiki hakekat ada, basis sesuatu sebagai ada, dan asal-muasal sesuatu. LihatLouis O. Kattsoff, Pengantar Filsafat, Taiara Wacana, Yogyakarta, 2004, hal. 185-187.

${ }^{19}$ Epistemologi adalah cabang filsafat yang menyelidiki asal mula, susunan, metode-metode dan sah tidaknya sebuah pengetahuan. Lihat Louis O. Kattsoff, Ibid., hal. 74.

${ }^{20}$ Aksiologi adalah cabang filsafat yang mengkaji masalah yang terkait dengan hakekat nilai (etika) dan keindahan (estetika) perbuatan/sesuatu. Lihat Louis O. Kattsoff, Ibid., hal. 317-378.
} 


\section{Dalil Naqli dan 'Aqli Iqra' dan Istiqra'}

Umumnya, dalil naqli mengenai jalan eksistensial ilmu pengetahuan merujuk pada beberapa ayat, salah satunya adalah QS. Al-'Alaq: 1-5. Aktifitas pengetahuan tentu saja harus diawali oleh dan dengan aktifitas membaca (qira'ah), baik membaca teks tertulis ataupun fenomena alam. Sebagai sumber teks tertulis, Al-Qur'an memuat beberapa dalil yang menyatakan mengenai urgensi jalan eksistensial ilmu, di antaranya disebutkannya kata langit, bumi, alam semesta, berpikir, ilmu, berilmu dan konsistensi lisan, akal dan tubuh dalam berkoordinasi secara empiris mengimplementasikan perbuatan. Dalil ini memperkuat dukungan serta kejujuran Al-Qur'an mengenai urgensi jalan eksistensial ilmu pengetahuan bagi manusia dan alam semesta. Karena di situlah letak eksplorasi ilmu pengetahuan untuk membedah alam semesta dan seisinya. Dengan iqra', seorang muslim dilatih secara displin dan penuh integrasi untuk mampu berpikir secara deduktif (iqra').

Sementara itu, secara 'aqli, dalil urgensi jalan eksistensial ilmu pengetahuan juga bisa dikembangkan dari istilah qiraah. Dalam bahasa Arab, kata tersebut bisa berkembang menjadi istiqra' setelah menjadi kata benda bentukan dari kata kerja (isim mashdar) dari kata kerja dengan tiga huruf tambahan alif, ta' dan siin. Kata yang disebut terakhir itu menandaskan tentang pentingnya berpikir induktif. Sebagaimana pencarian dan penelaahan ilmu pengetahuan selalu menggunakan pendekatan induktif, maka secara aqli, barangsiapa yang mengembangkan pemikiran dan telaah ilmu pengetahuan dengan pendekatan induktif tersebut, maka yang bersangkutan akan menemukan temuan baru, atau paling tidak menambahi argumen mengenai pentingnya ilmu pengetahuan. Dan sekali lagi, temuan-temuan yang dahulu kala ditemukan oleh para sarjana muslim, karena mereka dengan dukungan Al-Qur'an, telah melakukan telaah dan praktikum melalui pendekatan induksi secara terus-menerus telah membuktikan lahirnya generasi yang benar-benar fokus terhadap upaya invensi ilmu pengetahuan tersebut. Demikian juga yang terjadi di abad ini bahwa Barat dengan metode induksinya telah memajukan karya ilmu pengetahuan dan teknologinya. 
Namun demikian, keberhasilan telaah induktif harus dibarengi dengan sikap disiplin, integritas terhadap nilai dan lahirnya akhlak yang mulia secara keagamaan dan kemanusiaan. Konsep sulthan, perubahan mindset, dan iqra'istiqra' menandaskan tentang pentingnya nilai integritas sejak dalam proses belajar dan praksis implementasi ilmu pengetahuan baik dalam kaitan penghambaan kepada Allah (keagamaan) dan pengabdian kepada ruang publik kemanusiaan.

\section{Integritas Nilai Keagamaan dan Kemanusiaan}

Sub judul di poin ini adalah inti nilai sejati dari seorang muslim-mukmin yang menjadi aktor perubahan sosial bermental kreatif dan bermartabat. Siapakah mereka itu? Mereka adalah seorang muslim-mukmin yang sudah siap melakukan perubahan mindset, bahkan sudah melakukannya. Kemudian secara eksistensial mereka memilih jalan sulthan. Selanjutnya mereka kemudian melakukan iqra' dan istiqra' secara konsisten dan penuh integritas, baik kaitannya dengan hubungan mereka dengan Allah Swt maupun dengan ruang publik kemanusiaan.

Memang setelah iqra' dan istiqra' oleh pribadi yang memilih jalan sulthan sebagai jalan ilmu pengetahuannya, mereka harus melakukan suluk iqra' dan istiqra' yang saleh. Yaitu, suatu jalan eksistensial ilmu pengetahuan yang menjadikan landasan kesadaran dalam melakukan qiraah dan istiqra' melalui keyakinan berpikir bahwa ghayah (ujung) ilmu pengetahuan adalah pengakuan akan kemahaluasan ilmu Allah Swt. Itulah yang dicatat dengan baik oleh QS. Luqman: 27 dan QS. Al-Kahfi: 109, serta QS. Al-Baqarah: 32.

Dengan mengakui bahwa masih betapa luasnya ilmu Allah Swt., pelajaran berharganya adalah (i) kita akan terus-menerus melakukan pencarian. Mencari ilmu adalah kegiatan ilmiah yang tanpa akhir. Karena setiap ilmu baru pasti mengalami keusangan dan akan diganti dengan penemuan baru lagi. Maka, seorang muslim-mukmin actor perubahan sosial tidak akan pernah berhenti mencari ilmu pengetahuan; (ii) kita seharusnya menyadari dengan rendah hati bahwa klaim ilmu pengetahuan yang dipenuhi kesombongan akan selalu menyeleweng dari hakekat ilmu pengetahuan. Dengan kata lain, semakin orang mencari ilmu, dia seharusnya menjadi lebih rendah hati. 


\section{Piet Hizbullah Khaidir}

Dalil naqli di atas menandaskan bahwa ilmu pengetahuan harus juga dilandasi etika. Inilah yang nantinya membedakan ilmu yang berasal dari rahim sarjana muslim dan Barat. Karena itulah, seperti disitir Paul Feyeraben, meskipun ilmu pengetahuan membawa manfaat yang besar bagi perkembangan teknologi, diamdiam, sains yang berkembang di Barat yang tanpa nilai dan etika itu, telah menghancurkan demokrasi, kualitas kehidupan manusia dan kesejahteraannya. Jalan eksistensial Ilmu menurut Al-Qur'an adalah jalan ilmu yang dilandasi dengan moral etika Islam, yakni jalan ilmu yang ingin menghadirkan ilmu pengetahuan yang rendah hati dan bermanfaat bagi kesejahteraan dan martabat manusia.

Dalam kaitan itu, bukan berarti pengembangan dan perkembangan ilmu pengetahuan yang bersumber dari cahaya etis Al-Qur'an sepi tantangan, terutama bila dilihat dari aspek keilmuan dan pendidikan. Tantangan umat Islam dalam bingkai keilmuan dan pendidikan adalah bagaimana dapat menjaga lahirnya ilmu dalam Islam sebagai kajian, pilar pencerahan dan peradaban serta landasan moral. Kearah tujuan tersebut umat Islam dan Al-Qur'annya harus terus hidup sebagai kawah candradimuka keilmuan yang nihayat ghayahnya (tujuan akhirnya) adalah penghambaan yang tulus kepada Allah Swt., dalam berupaya melahirkan wadah tarbiyah Islamiyah.

Tantangan konseptual di atas perlu diejawantahkan lebih jauh ke dalam lembaga pendidikan. Dus, perlu dilanjutkan kepada pelembagaan ilmu pengetahuan dan pembudayaannya dalam bingkai lembaga pendidikan. Pelembagaan dan pembudayaan ini penting, karena ilmu dan amal adalah sisi dua mata uang yang tidak boleh dipisahkan. Dalam Islam, ilmu tertinggi (the ultimate knowledge) adalah kepercayaan (iman). Kepercayaan harus ditindak-lanjuti dengan pengamalan. Kepercayaan dan pengamalan yang dilakukan terus-menerus akan menjadi pembudayaan. Inilah akhlak, yakni upaya pembiasaan kebaikan dalam sinaran ilmu pengetahuan.

Output dengan karakter mental kreatif dan bermartabat dengan sinaran konsep perubahan mindset, sulthan, iqra'-istiqra' dan integritas yang didesain mengejawantah dalam proses dan tindak lanjut pendidikan di atas adalah tarbiyah revolusioner yang dibutuhkan dalam rangka mewujudkan aktor perubahan sosial 
yang siap lahir batin dalam menghadapi masa depannya: dengan ilmu pengetahuan dan keyakinan yang solid terhadap Allah Swt. Inilah kunci aktor perubahan sosial yang akan sukses lahir dan batin dalam menggapai peradaban Islam dengan kebajikan semesta.

\section{Dari Gerakan Individu ke Gerakan Sosial}

Aktor dengan tipologi di atas untuk mewujudkan perubahan sosial harus bergerak dari fakta individual ke fakta sosial. Dari gerakan individu ke gerakan sosial. Untuk pembahasan ini, akan diurai pembelajaran dari kandungan dari AlFatihah dan Al-Muzzammil.

Al-Fatihah dan Al-Muzzammil dalam konteks perubahan sosial dari gerakan individu ke gerakan sosial memberikan panduan umum bahwa dalam mencanangkan perubahan sosial seseorang diharapkan tidaklah pernah berharap apa-apa dari yang dilakukannya. Bergerak tanpa pamrih.

Ketika sudah mampu bergerak tanpa pamrih, dengan penataan hati yang kuat pada Allah, seorang individu akan benar-benar sanggup memperoleh amanah qaulan tsaqilan (Al-Muzzammil). Yakni mewujudkan perubahan sosial mendasar yang akan mengarahkan kepada kemakmuran hebat seperti Hijaz (Makkah dan Madinah). Dengan kondisi Hijaz yang sangat tandus tanahnya dan keras hati penduduknya, sangat tidak mungkin Nabi Ibrahim dan Ismail As, dan Nabi Muhammad Saw dapat melakukan perubahan sosial di Hijaz, tanpa bantuan kekuatan spiritual dari Allah Swt.

Oleh karena itu, panduan Al-Fatihah dan Al-Muzzammil dalam kaitan dengan membangun strategi perubahan sosial adalah sebagai berikut: Pertama, satukan iman dan ilmu (Al-Fatihah: 1-3). Kedua, kuatkan ibadah dan ikhtiyar (Al-Fatihah: 5). Ketiga, kembangkan hidayah dan perluas jejaring berbagi nikmat kemakmuran/barakah (Al-Fatihah: 6-7). Keempat, selamatkan diri dari fitnah gerakan dan kesesatan berpikir (Al-Fatihah: 7).

Untuk mampu melakukan ini secara gerakan sosial, seorang individu atau sekelompok individu harus melakukan pamaparan Al-Muzzammil sebagai panduannya, yaitu: Pertama, qiyamul layl (merenung dan mendekatkan diri secara 


\section{Piet Hizbullah Khaidir}

spiritual kepada Yang Maha Melakukan Perubahan). Kedua, membaca Alquran (memperbaharui wawasan keilmuan dan pengalaman).

Ketiga, berdzikir terus-menerus (mengingat terus-menerus akan pertolongan Allah). Keempat, tawakkal dan sabar (konsisten dan persisten dalam membangun gerakan sosial untuk perubahan. Tidak mundur hingga dianugerahi kemenangan al-fath). Terakhir, hijrah. Melakukan perubahan sosial bukan sekedar fisik dan karitatif. Tetapi, benar-benar lahir batin serta sistemik semua diri dan komunitas berhijrah untuk melakukan perubahan.

Ghayah perubahan sosial terdapat pada akhir Surat Al-Muzzammil dan Al'Alaq. Yakni, mengabdi dengan ibadah sejati mendekatkan diri kepada Allah. Bersujud bersimpuh menyerahkan jiwa raga hanya untuk Allah. Seraya mohon ampun kepada Allah jika dalam proses melakukan perubahan sosial ada kesalahan niat dan cara yang tidak diperkenankan.

Perubahan sosial bukanlah untuk perubahan sosial itu sendiri. Tetapi, untuk semakin menggapai kualitas taqarrub dan sujud kita kepada Sang Penguasa alam semesta. Inilah mungkin yang bisa disebut sebagai perubahan sosial dengan strategi ilahi.

\section{Kesimpulan}

Dari uraian di atas dapat disimpulkan beberapa hal berikut ini:

Pertama, hal terpenting dalam proses melakukan perubahan sosial menurut al-Qur'an adalah pentingnya perubahan mindset. Seseorang tanpa upaya melakukan perubahan mindset, kemungkinan besar tidak akan dapat melakukan perubahan social.

Kedua, perubahan mindset harus dilakukan dengan nalar jalan ilmu pengetahuan. Nalar jalan ilmu pengetahuan sebagaimana petunjuk al-Qur'an dapat diurai dari konsep sulthan; dicapai dengan baca tulis yang dibiasakan dengan integritas tinggi demi mencapai akhlak kebajikan semesta dalam rangka menghormati martabat kemanusiaan dalam bingkai akhlak karimah universal.

Terakhir, al-Qur'an memiliki panduan praktis perubahan sosial, sebagaimana diurai dalam QS. Al-Fatihah dan QS. Al-Muzzammil. Kesejatian perubahan sosial 
itu terletak pada konsistensi, penghambaan nan tulus dan kerendahhatian dalam menggapai tujuan akhir perubahan sosial untuk peradaban, yaitu: menggapai kualitas taqarrub dan sujud kita kepada Sang Penguasa alam semesta.

\section{Daftar Pustaka}

Al-Qur'an dan Terjemahannya, Khadim al-Haramayn, $1418 \mathrm{H}$.

Baghawi (al), Al-Syaikh Ibn Al-Farra'. Tafsir Al-Baghawi, Jilid 4. Beirut: Dar Ihya Al-Turats Al-Arabiy [dalam Maktabah Syamilah Ar-Rawdah (www.shamela.ws) cetakan ke-7], $1420 \mathrm{H}$.

Kattsoff, Louis O. Pengantar Filsafat. Yogyakarta: Tiara Wacana, 2004.

Kemenag, Qur'an. Aplikasi Mushaf Digital. Jakarta: Kemenag RI, cq. Lajnah Pentashihan Mushaf Al-Qur'an, 2007.

Qurthubi (al), Al-Syaikh. Tafsir Al-Qurthubi, Jilid 14. Mesir: Dar Al-Kutub AlMishriyah [dalam Maktabah Syamilah Ar-Rawdah (www.shamela.ws) cetakan ke-7], 1964.

Quthb, Sayyid. Tafsir Fi Zilalil Qur'an, Jilid VII. Depok: Gema Insani, 2004.

Zarkasyi (al), Al-Syaikh. Al-Burhan fi Ulum Al-Qur'an, Juz 4. Mesir: Al-Halabiy [dalam Maktabah Syamilah Ar-Rawdah (www.shamela.ws), cetakan ke7], 1957.

Bacchus, M.K. "Education, Cultural Change and Cultural Pluralism", JSTOR Journal of American Sociology of Education, USA, Vol. 42, No. 04 (1969).

https://ayatalquran.net/2014/12/surah-ar-radu-terjemah-bahasa-indonesia/, last accessed 01 October 2019, at 12:17

https://ayatalquran.net/2014/12/surah-al-anfaal-terjemah-bahasa-indonesia/, last accessed 01/10/'19, at 12:50

https://ayatalquran.net/2014/12/surah-al-alaq$\% \mathrm{~d} 8 \% \mathrm{a} 7 \% \mathrm{~d} 9 \% 84 \% \mathrm{~d} 8 \% \mathrm{~b} 9 \% \mathrm{~d} 9 \% 84 \% \mathrm{~d} 9 \% 82$-terjemah-bahasa-indonesia/, last accessed $01 / 10 /{ }^{\prime} 19$, at $12: 41$ 


\section{Piet Hizbullah Khaidir}

https://www.youtube.com/watch? $\mathrm{v}=\mathrm{jCm} 3$ BemDlj8 (winning speech), last accessed 30/09/'19, at 15:54

https://www.youtube.com/watch?v=aFWwO7RR2QM (match Serena Vs Naomi), last accessed 30/09/' 19 , at 15:54

www.sederet.com, last accessed 18 September 2019. 